\title{
Grasslands feeling the heat: The effects of elevated temperatures on a subtropical grassland
}



Background: Tropical and subtropical Africa is predicted to experience a rise in temperature. The effects of rising temperatures on temperate grasslands have been studied using open-top chambers (OTCs) but reports for tropical/subtropical grasslands are scarce. This study used OTCs to investigate the effects of elevated temperatures on a threatened subtropical grassland type, namely KwaZulu-Natal Sandstone Sourveld (KZNSS).

Objectives: To assess the effects of OTCs on selected abiotic parameters and plant productivity within KZNSS.

Methods: Five OTC and control plots were randomly distributed at the same altitude within a patch of KZNSS. Air and soil temperature, relative humidity $(\mathrm{RH})$, soil moisture content and light intensity were monitored in all plots in spring, summer, autumn and winter. Biomass production and plant density were measured in each season, for each life form (graminoid, forb and shrub), separately and combined.

Results: The OTCs resulted in a rise in average, maximum and minimum day and night, air and soil temperatures. This increase, the degree of which differed across seasons, was accompanied by a decline in $\mathrm{RH}$ and soil moisture content. Elevated temperatures led to a significant increase in combined, graminoid and shrub above-ground productivity (AGP) and a decrease in forb density, but in certain seasons only. Below-ground biomass production was unaffected by elevated temperatures.

Conclusions: OTCs can simulate realistic increases of air temperature in subtropical grasslands. Graminoids and shrubs appear to benefit from elevated temperatures whilst forbs decrease in abundance, possibly through competition and/or direct physiological effects.

\section{Introduction}

Extreme weather events, changes in precipitation, considerable variation in temperature and sea level rise provide evidence for global climate change (Dhillon \& Wuenhlish 2013). Climate change, suggested to be largely a consequence of anthropogenic activities (Dhillon \& Wuenhlish 2013), has impacted negatively on plant biodiversity in terms of both distribution and diversity (Trisurat, Shrestha \& Kjelgren 2011).

Increasing temperatures, in particular, are likely to have a number of effects on plant communities globally (De Boeck et al. 2007). Global surface temperatures have risen by approximately $0.8{ }^{\circ} \mathrm{C}$ over the last century and are predicted to increase by $1.4-5.8{ }^{\circ} \mathrm{C}$ during the $21^{\text {st }}$ century (Intergovernmental Panel on Climate Change [IPCC] 2007). In Africa, this increase in temperature is predicted to result in longer growing periods, higher fecundity, higher biomass allocation towards roots, and a possible shift towards tree-dominated biomes (Scheiter \& Higgins 2009).

Predicting ecosystem responses to climate change is therefore becoming increasingly important, particularly in tropical regions, where species occupy narrow ranges owing to thermal specialisation (Laurance et al. 2011). These areas are likely to experience the greatest loss in biodiversity with an increase in temperature (Perez, Stroud \& Feeley 2016). The effects of rising temperatures on grasslands is an important consideration given their high biodiversity (Boval \& Dixon 2012), particularly in the tropics, where they occupy approximately $20 \%$ land cover (Parr et al. 2014). Grasslands play a particularly important role in carbon sequestration and nutrient recycling (Boval \& Dixon 2012), and are threatened in many parts of the world by land-use change, poor management and climate change (Jewitt 2011; Parr et al. 2014; Sala et al. 2000). 
The grassland biome in South Africa boasts high levels of endemic mammals, reptiles, butterflies, and very high levels of plant species diversity (Reyers et al. 2005). However, an estimated 35\% of South African grassland has been either transformed or degraded (Egoh et al. 2011). An understanding of how grassland vegetation types will respond to, or be impacted on, by increased temperatures can inform their future conservation and management (Thuiller et al. 2008). Various climate change models and numerous in and ex situ experiments have attempted to predict and demonstrate the effects of rising temperatures within temperate grasslands (Flanagan \& Johnson 2005; Godfree et al. 2011; Ojima et al. 1993), but effects on tropical and subtropical grasslands have received less attention (Godfree et al. 2011). Nevertheless, one of the major effects of rising temperatures on grassland and other biomes is predicted to be altered plant productivity (Guoju et al. 2005). Plant productivity, or more correctly net primary productivity (NPP), is the net rate of carbon (C) gain incorporated into plant vegetation over a given time period (Girardin et al. 2010; Long \& Hutchin 1991). It represents a large portion of organic matter consumed by animals and microbes. Changes in NPP can therefore impact the quantity and quality of food available to animals, including humans (Potter, Klooster \& Genovese 2012). In regions where plant carbon assimilation is limited because of low temperatures, increased temperatures could increase NPP (De Boeck et al. 2007); however, these responses are likely to be species and life form dependent (Lattanzi 2010; Luo et al. 2013; Wand et al. 1999).

Plants undergo physiological changes such as altered carbon assimilation rates when subjected to increased temperatures (Ahuja et al. 2010; Saxe et al. 2001). The effects of increased temperature are not universal - for example, $C_{3}$ and $C_{4}$ plants show different physiological responses to elevated temperatures (Horton \& Murchie 2000; Sage 2000). $C_{4}$ plants have a carbon fixation pathway that is far less sensitive to an increase in temperature than $\mathrm{C}_{3}$ types (Gowik \& Westhoff 2011). In fact, $\mathrm{C}_{4}$ crops and grasses are $40 \%$ more efficient at converting photosynthetically active radiation (PAR) into biomass than $C_{3}$ types in general (Long 1999). In warmer climates, the greater efficiency of $\mathrm{C}_{4}$ photosynthesis at higher temperatures is likely to result in higher NPP in $\mathrm{C}_{4}$ relative to $\mathrm{C}_{3}$ species, particularly in low-latitude grasslands, deserts and coastal zones (Sage 2000). These differences in NPP between $\mathrm{C}_{3}$ and $\mathrm{C}_{4}$ species can impact on species composition and richness by altering competitive interactions (Wand et al. 1999).

Increased temperatures, in altering the standing biomass, can also impact on fire regimes, which are an essential part of grassland ecology (Trollope, Trollope \& Hartnett 2002). Global warming is therefore expected to impact the carbon budget as a consequence of changes to plant photosynthesis and growth, as well as soil respiration (Schindlbacher, Zechmeister-Boltenstern \& Jandl 2009; Wan et al. 2005). More specifically, changes in carbon cycling induced by global warming, as a result of changes in NPP and heterotrophic respiration, can influence whether terrestrial ecosystems act as carbon sources or sinks (Wan et al. 2005). Increased evaporative cooling in the leaves, another predicted consequence of increased temperature, can also induce water stress in certain plant species (Beerling, Osborne \& Chaloner 2001) and impact on ecosystem hydrology (Williams \& Scott 2009). An increase in temperature is usually accompanied by a subsequent increase in water deficit, restricting plant growth and photosynthesis, which leads to varied effects in different ecosystems (De Boeck et al. 2007; Wan, Luo \& Wallace 2002). This implies that both stresses, temperature and water deficit, and their interactive effects need to be considered when assessing plant responses to increased temperature.

The use of open-top chambers (OTCs) for studying the effects of simulated elevated temperatures on grassland (and other) vegetation has recently gained more interest, but predominantly in temperate and polar regions (Flanagan \& Johnson 2005; Flanagan, Sharp \& Letts 2013; Molau \& Mølgaard 1996). However, the utility of these chambers in studying the effects of elevated temperatures on tropical and subtropical vegetation has yet to be established. This, and the likelihood that Africa will experience some of the greatest increases in temperature (IPCC 2007), prompted the present study, which used OTCs to assess the in situ growth and community structure responses of subtropical grassland vegetation to elevated temperatures. This study was conducted in a remnant patch of KwaZulu-Natal Sandstone Sourveld (KZNSS) in Durban, South Africa. This grassland type is located along the coastal belt of KwaZulu-Natal and is home to a number of endemic species (Mucina \& Rutherford 2006). It is highly transformed and critically endangered (Jewitt 2011). The study assessed whether OTCs can simulate realistic increases (i.e. increases in line with predictions for this century) in temperatures in a subtropical grassland. More importantly, the effects of OTCs on soil and air temperature and a range of abiotic parameters (relative humidity, soil moisture content and light intensity) are related to seasonal and annual plant productivity and density responses across different life forms.

\section{Methods}

\section{Site selection and experimental approach}

The study site was a remnant patch of KZNSS located within Tanglewood Nature Reserve, in the eThekwini Municipal Area (Durban), South Africa (29 $\left.48^{\prime} 37^{\prime \prime} S, 30^{\circ} 49^{\prime} 18^{\prime \prime} \mathrm{E}\right)$. Five experimental (OTC) and five control, hexagonally shaped plots, approximately $2.012 \mathrm{~m}^{2}$, were randomly distributed along a south-east facing slope at approximately the same altitude (425 $\mathrm{m}$ above sea level). Each experimental plot was paired with a control plot, located within $2 \mathrm{~m}$ of each other. The vegetation in all plots was cut to ground-level and the soil was disked to promote seedling recruitment through softening the soil and splitting of grass roots (Farooq et al. 2011; van Acker, Bullied \& du Croix Sissons 2004). Once the plots were prepared, hexagonal polycarbonate OTCs (described below) were installed in all experimental plots. The OTCs were installed and left in place for 2 months during 
each of the four seasons (spring: 1 September - 30 November; summer: 1 December - 28/29 February; autumn: 1 March 31 May; winter: 1 June -31 August).

Several antelope species (e.g. blesbok [Damaliscus pygargus phillipsi], bushbuck [Tragelaphus sp.] and zebra [Equus quagga]) occur on the reserve, and to prevent the potential confounding effects of herbivory, the control plots were enclosed by $1.5 \mathrm{~m}$ high wire fence.

\section{Chamber construction}

The OTCs used in this study are based on a design modified from the International Tundra Experiment (ITEX) (Molau \& Mølgaard 1996). The chambers were hexagonal in shape (see Figure 1 for dimensions) and constructed using clear $2 \mathrm{~mm}$ thick Naxel polycarbonate sheeting (Maizey Engineering Plastic Products, New Germany, South Africa), which has a light transmittance of $\pm 90 \%$. The frame supporting the polycarbonate was constructed from $20 \mathrm{~mm}$ plastic conduit tubing. The OTCs were secured to the ground using steel pegs.

\section{Measurement of environmental parameters}

Air and soil temperatures were monitored across all plots (control and treatment) throughout the experimental period using digital temperature loggers (Thermochron iButton Device - DS1921G, Maxim Integrated ${ }^{\mathrm{TM}}$, San Jose, USA), placed $5 \mathrm{~cm}$ below ground level for soil temperature and 10 $\mathrm{cm}$ above ground level for air temperature. Four temperature loggers were used in each control $(n=20)$ and six $(n=30)$ within each experimental plot. The Thermochrons were programmed to record temperatures on an hourly basis throughout the experimental period. Their positioning within the control and OTC plots is shown in Figure 1c.

Additionally, air temperature and relative humidity $(\mathrm{RH})$ were measured in all plots $25 \mathrm{~cm}$ above ground level using a 4500 Pocket Weather Tracker (Kestrel, Birmingham, UK) weekly (at midday). Soil moisture content and light intensity were also measured weekly (at midday) using a Soil Moisture Meter (HH2 Moisture Meter, Delta-T Devices, Cambridge, UK) and a Digital Light Meter (ESR-1, PP Systems, Amesbury, USA). The positions at which these measurements were carried out within the OTC plots are shown in Figure 1c. Weekly rainfall data were collected using a standard nonrecording rain gauge. Seasonal rainfall was calculated by summing the weekly rainfall data.

\section{Plant growth measurements}

At the start of each season, immediately before installing the OTCs, soil cores were taken along the immediate periphery of (but external to) all plots, using a soil corer $(18 \mathrm{~cm}$ long by $4.75 \mathrm{~cm}$ wide). A total of three cores were taken for each plot ( $n=15$ for control and OTC) in each season and these were stored at $-18^{\circ} \mathrm{C}$. After the 2-month experimental period, soil cores were performed again for each plot $(n=15$ for control and OTC), but this time within each plot. Soil cores were

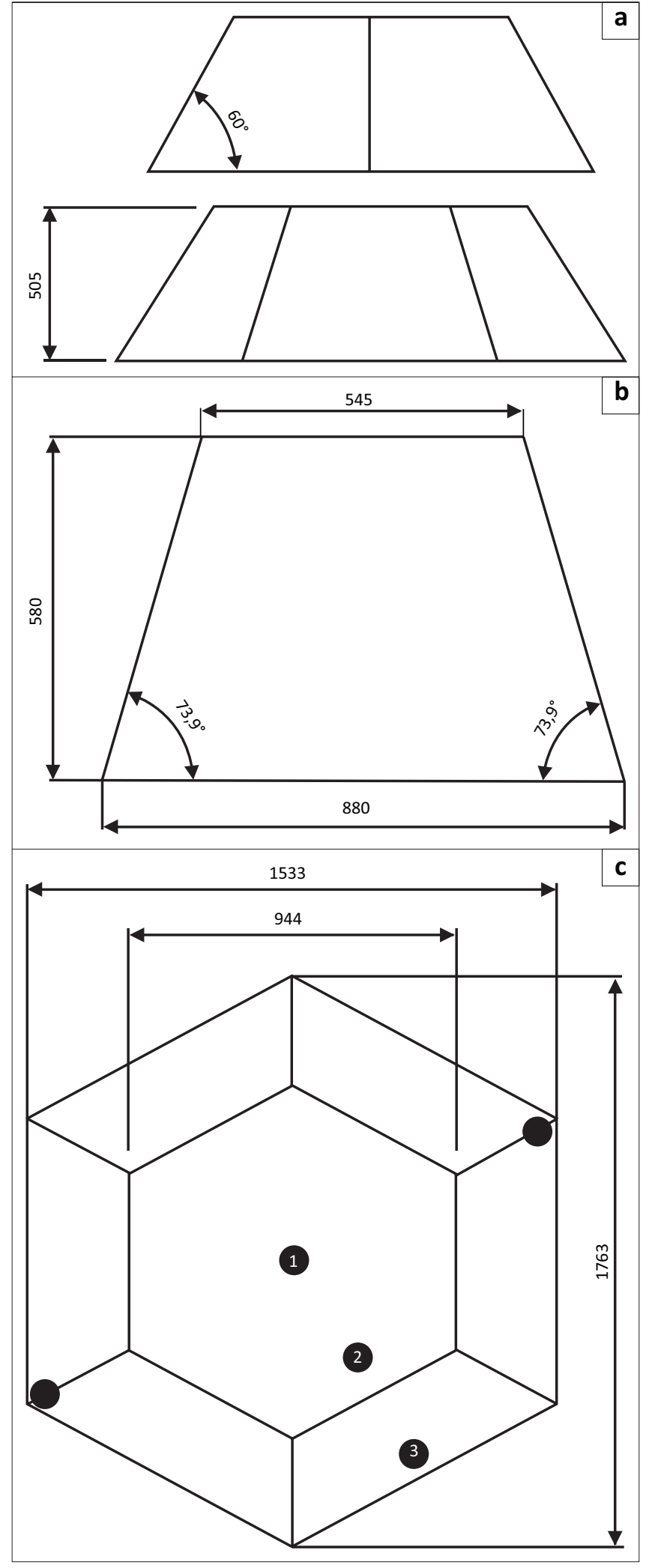

FIGURE 1: Open-top chamber design modified from Molau and Molgaard (1996). Side view (a), individual panel of chamber (b), and top view (c). The black circles indicate locations at which light intensity, relative humidity and temperatures measurements were conducted at midday $(n=5)$, whilst the numbered black circles indicate where digital temperature loggers were positioned.

rinsed under running water with a sieve to free roots of soil and dead roots were removed. The total (indiscriminate) root dry mass was determined by drying the roots collected at 
$75{ }^{\circ} \mathrm{C}$ for $72 \mathrm{~h}$, and then weighing these using a three-place balance (Mettler Toledo, Columbus, USA).

The above-ground biomass of each plant, which was categorised based on life form (graminoid, forb or shrub), within all plots was harvested and placed in separate paper bags. The plant material was dried at $75^{\circ} \mathrm{C}$ for $72 \mathrm{~h}$, and then weighed using a three-place balance (Mettler Toledo, Columbus, USA). Biomass production (grams of dry mass [g]) was compared between control and OTC plots, within life forms for above-ground biomass production (AGP). Within life form comparisons were not possible for belowground biomass production (BGP) as roots could not be separated into individual species/life forms.

\section{Statistical analysis}

All data were tested for normality using either the Kolmogorov-Smirnov or Shapiro-Wilk test, depending on sample size. Percentage data were arcsine transformed prior to any analyses. As initial analyses revealed no significant differences in temperature across different locations within individual plots (control and OTC), these data were pooled for all subsequent analyses. Significant differences between control and OTC plots for all environmental parameters (midday temperature, $\mathrm{RH}$, soil moisture content and light intensity) were tested within seasons via a Wilcoxon signedrank test, as all data were non-parametric. For the Thermochron readings, differences between control and OTC plots were tested for within 3-hour intervals (00:00-03:00; 03:00-06:00; 06:00-09:00; 09:00-12:00; 12:00-15:00; 15:0018:00; 18:00-21:00; 21:00-24:00) using a Wilcoxon signed-rank test within each season. The maximum and minimum temperatures for each Thermochron within OTC plots and within control plots were averaged seasonally to determine the average maximum and minimum temperatures. The highest and lowest temperature reading for each season (in OTC s and control plots) was labelled absolute maximum and absolute minimum temperature.

Seasonal plant densities were determined for each life form by dividing the number of individual plants by the plot size $\left(2.012 \mathrm{~m}^{2}\right)$. Above-ground biomass allocation was calculated by expressing the AGP for each life form as a percentage of the total AGP for all life forms combined. Comparisons of AGP, BGP, above-ground biomass allocation and plant densities between control and OTC plots were made within and across life forms using a Wilcoxon signed-rank test. Pearson's correlation was used to determine the relationship between the abiotic parameters (temperature, $\mathrm{RH}$ and soil moisture content) and AGP, above-ground biomass allocation and plant density. Where applicable, non-parametric data were tested with a Spearman's rank correlation. All statistical analyses were performed using IBM SPSS Statistics 21 (SPSS IBM, New York, USA) and differences were considered significant at the 0.05 level.

\section{Results}

The results presented below reflect the effects of open-top chambers (OTCs) on in situ temperatures, other abiotic factors, and plant productivity and community structure. Measurements were conducted in each of the four seasons.

\section{Diurnal air and soil temperature in control and OTC plots}

Diurnal patterns of variation in temperature were similar in OTC and control plots in all seasons (Figure 2), with the highest temperatures occurring between 11:00 and 12:00 and lowest between 04:00 and 06:00. The air and soil OTC temperatures were significantly ( $p<0.05$ in all cases) higher than the control temperatures for all day and night 3-hour intervals, in all seasons.

Air temperature differences between OTC and control plots were most marked during the day between 12:00 and 14:00, except for summer when differences were at a maximum between 09:00 and11:00. At night these differences were most marked between 21:00 and 23:00 in autumn, 18:00 and 20:00 in winter and spring, and 03:00 and 05:00 in summer. These differences across time intervals were less apparent for soil temperatures.

Additionally, the OTCs increased the diurnal absolute maximum air and soil temperatures, ranging between $4.4{ }^{\circ} \mathrm{C}$ and $5.7{ }^{\circ} \mathrm{C}$ and $0.9{ }^{\circ} \mathrm{C}$ and $1.8^{\circ} \mathrm{C}$, respectively, and also increased absolute minimum air and soil temperatures, ranging between $0.3{ }^{\circ} \mathrm{C}$ and $2.0^{\circ} \mathrm{C}$ and $0.3{ }^{\circ} \mathrm{C}$ and $0.8{ }^{\circ} \mathrm{C}$, respectively (Table 1$)$. The OTCs had significantly $(p<0.05)$ higher average day and night, air and soil maximums in all seasons, except for winter night air temperature, and had significantly higher average day and night, air and soil minimums in all seasons, except for winter day air temperature (data not shown). When data on the degree of temperature increase induced by OTCs were compared within seasons, the OTCs significantly $(p<0.05)$ increased the day air (by $1.7^{\circ} \mathrm{C}-2.4^{\circ} \mathrm{C}$; Figure 3a) and soil (by $0.7^{\circ} \mathrm{C}-$ $1.0{ }^{\circ} \mathrm{C}$; Figure 3a) temperatures, and night air (by $0.3{ }^{\circ} \mathrm{C}-$ $0.6{ }^{\circ} \mathrm{C}$; Figure $3 \mathrm{~b}$ ) and soil (by $0.5{ }^{\circ} \mathrm{C}-1.2{ }^{\circ} \mathrm{C}$; Figure $3 \mathrm{~b}$ ) temperatures in all seasons relative to the control, with the exception of night air temperature in winter.

In spring, the OTCs experienced the greatest increase in day air temperature and smallest increase in day soil temperature, whilst autumn was characterised by the smallest increase in day air temperature and highest increase in day soil temperature (Figure $3 a$ and $3 b$ ). In autumn, the OTCs experienced the greatest increase in night air and soil temperature, whilst spring and summer had the smallest increase in night air and soil temperature, respectively.

When temperature data for the different seasons were pooled within day and within night for analysis, referred to as 'annual' data henceforth, it was evident that the OTCs increased air and soil temperatures for both day and night significantly ( $p<0.05$; Figure $3 \mathrm{a}$ and $3 \mathrm{~b}$ respectively). The OTC plots increased the annual day and night air temperatures 


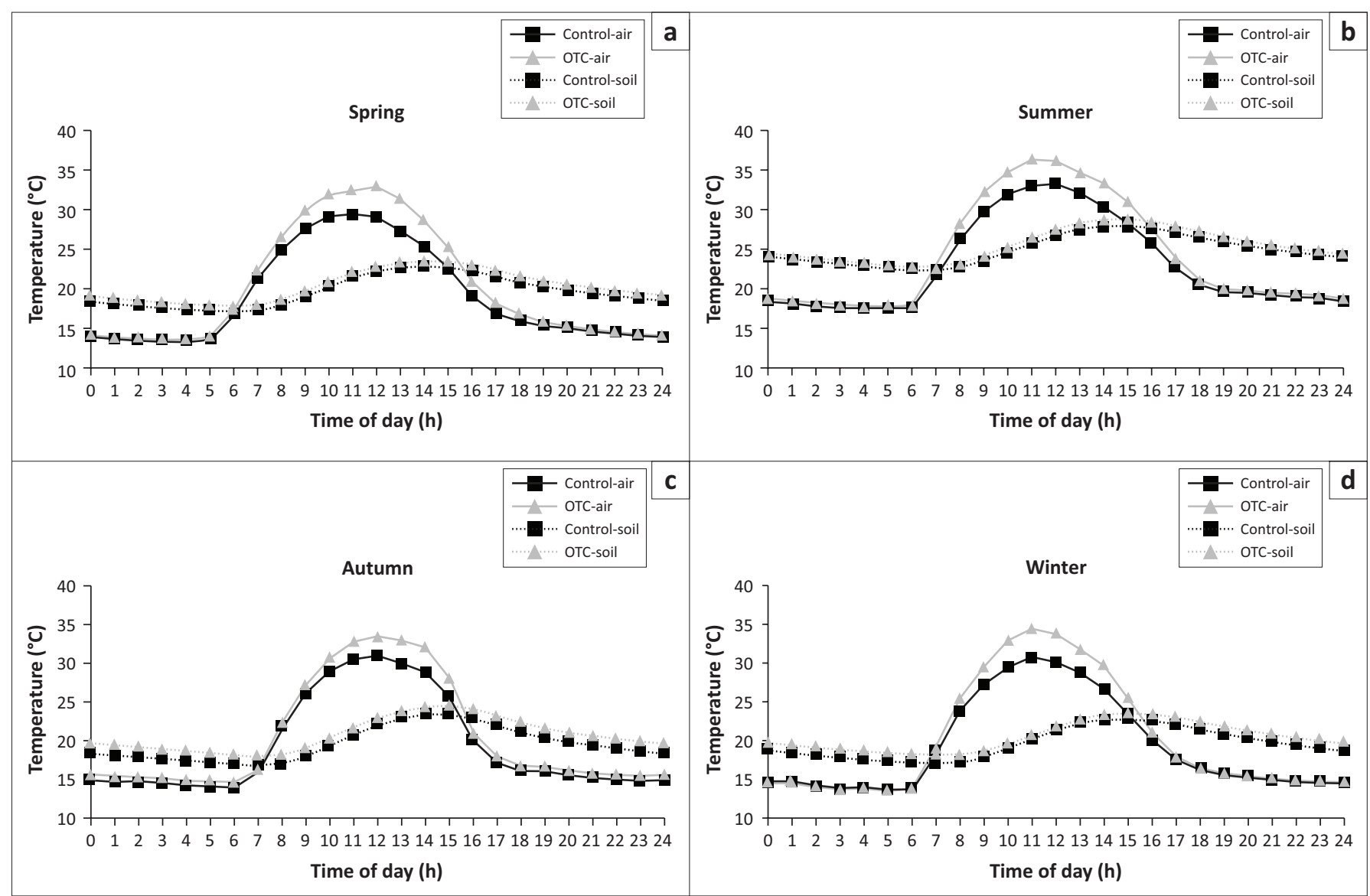

FIGURE 2: Diurnal variation in air and soil temperature in OTC and control plots in spring (a), summer (b), autumn (c) and winter (d). Air temperature values represent means, with $n=10240$ for spring, summer and autumn; and $n=9665$ for winter. For soil temperature values represent means, with $n=10240$ for spring, summer and autumn; $n=9665$ for winter. $P<0.05$ when air and soil temperatures were compared within three hour intervals in each the four seasons (Wilcoxon signed-rank test). Standard deviations ranged from $2.16-9.98^{\circ} \mathrm{C}$ for air temperatures and $2.09-3.97^{\circ} \mathrm{C}$ for soil temperatures.

TABLE 1: Seasonal and annual mean, absolute maximum and absolute minimum temperatures for OTC and control plots.

\begin{tabular}{|c|c|c|c|c|c|c|c|c|c|c|c|}
\hline & & \multicolumn{2}{|c|}{ Annual } & \multicolumn{2}{|c|}{ Spring } & \multicolumn{2}{|c|}{ Summer } & \multicolumn{2}{|c|}{ Autumn } & \multicolumn{2}{|c|}{ Winter } \\
\hline & & Ambient & Elevated & Ambient & Elevated & Ambient & Elevated & Ambient & Elevated & Ambient & Elevated \\
\hline \multirow[t]{2}{*}{ Mean } & Air & $20.1 \pm 7.6$ & $21.3 \pm 8.9$ & $19.2 \pm 7.6$ & $20.5 \pm 9.4$ & $23.2 \pm 7$ & $24.5 \pm 8.4$ & $18.2 \pm 7.5$ & $19.3 \pm 8.3$ & $19.5 \pm 7.3$ & $20.5 \pm 8.7$ \\
\hline & Soil & $20.8 \pm 4.3$ & $21.7 \pm 4.3$ & $19.7 \pm 3.4$ & $20.4 \pm 3.4$ & $24.9 \pm 3.3$ & $25.5 \pm 3.7$ & $18.2 \pm 3.3$ & $19.4 \pm 3.2$ & $19.7 \pm 3.2$ & $20.6 \pm 3.1$ \\
\hline \multirow{2}{*}{$\begin{array}{l}\text { Absolute } \\
\text { maximum }\end{array}$} & Air & 45,4 & 51,1 & 45,2 & 49,6 & 44,1 & 49,5 & 45 & 50 & 45,4 & 51,1 \\
\hline & Soil & 35,9 & 37,7 & 30,7 & 31,9 & 35,9 & 37,7 & 30,5 & 31,4 & 29,9 & 30,8 \\
\hline \multirow{2}{*}{$\begin{array}{l}\text { Absolute } \\
\text { minimum }\end{array}$} & Air & 5,9 & 6,2 & 6,8 & 7,7 & 10,3 & 12,3 & 7,1 & 8,7 & 5,9 & 6,2 \\
\hline & Soil & 11,5 & 12,1 & 11,8 & 12,1 & 17,2 & 17,6 & 13,2 & 14 & 11,5 & 12,1 \\
\hline
\end{tabular}

Values in second row represent means \pm SD.

$n=10240$ in spring, summer and autumn; $n=9665$ in winter.

$P<0.05$ (Wilcoxon signed-rank test) when means were compared within seasonal categories between temperature treatments.

by $2.1{ }^{\circ} \mathrm{C}$ and $0.3{ }^{\circ} \mathrm{C}$ (Figure 3a), and soil temperatures by $0.8^{\circ} \mathrm{C}$ and $0.8^{\circ} \mathrm{C}$, respectively (Figure $3 \mathrm{~b}$ ).

Midday temperature, $\mathrm{RH}$ and soil moisture content, differed significantly $(p<0.05)$ between OTC and control plots in all seasons (Table 2). Average midday OTC temperature readings were significantly $(p<0.05)$ higher than those in control plots; however, the OTC plots exhibited significantly $(p<0.05)$ lower $\mathrm{RH}$ and soil moisture content in all seasons (Table 2). Light intensity was significantly $(p<0.05)$ lower in OTC plots in spring, summer and winter; however, these differences were minimal, ranging from 70.59-110.39 $\mu \mathrm{mol} \mathrm{m}^{-2} \mathrm{~s}^{-1}$ (Table 2). When control and OTC data for all seasons were pooled for analysis (annual data), there was a strong negative correlation $(r=-0.745--0.910, p<0.05)$ between temperature and $\mathrm{RH}$ and within seasons there was a strong positive correlation between $\mathrm{RH}$ and soil moisture content in spring $(r=0.818, p<0.05)$ and summer $(r=$ $0.811, p<0.05)$.

There was a large variation in the total rainfall across seasons: $313 \mathrm{~mm}$ in spring, $198.5 \mathrm{~mm}$ in summer, $46.5 \mathrm{~mm}$ in autumn and $13.5 \mathrm{~mm}$ in winter.

\section{Growth responses}

In both OTC and control plots, the highest annual AGP (i.e. all seasons summed) occurred in graminoids, followed by forbs and shrubs (Figure 4). Biomass production for 



FIGURE 3: Average increase in temperature (annual and seasonal) within OTC plots, relative to control plots, for air (a) and soil (b). For air and soil measurements $n=40385$ for annual; $n=10240$ for spring, summer and autumn; $n=9665$ for winter. Standard deviations ranged from $1.56-1.82{ }^{\circ} \mathrm{C}$ for day, and $0.29-0.53{ }^{\circ} \mathrm{C}$ for night air temperature; and from $0.38-0.49^{\circ} \mathrm{C}$ for day, and $0.34-0.47^{\circ} \mathrm{C}$ for night soil temperature.

TABLE 2: Seasonal midday air temperature $\left({ }^{\circ} \mathrm{C}\right)$, relative humidity $(\%)$, soil moisture content $(\%)$, light intensity $\left(\mu \mathrm{mol} \mathrm{m}^{-2} \mathrm{~s}^{-1}\right)$ and total rainfall $(\mathrm{mm})$ for OTC and control plots.

\begin{tabular}{|c|c|c|c|c|c|c|}
\hline Season & Elevated/Ambient & Air Temperature $\left({ }^{\circ} \mathrm{C}\right)$ & Relative Humidity (\%) & Soil Moisture Content (\%) & Light Intensity $\left(\mu \mathrm{mol} \mathrm{m}{ }^{-2} \mathrm{~s}^{-1}\right)$ & Total Rainfall (mm) \\
\hline \multirow[t]{2}{*}{ Spring } & Elevated & $32.07 \pm 4.47$ & $39.2 \pm 12.46$ & $7.76 \pm 3.34$ & $691.41 \pm 165.84$ & 313 \\
\hline & Ambient & $28.2 \pm 3.69$ & $46.52 \pm 14.55$ & $9.85 \pm 4.10$ & $762 \pm 84.14$ & \\
\hline \multirow[t]{2}{*}{ Summer } & Elevated & $35.3 \pm 3.13$ & $49.89 \pm 5.02$ & $14.57 \pm 4.14$ & $713.67 \pm 166.12$ & 198,5 \\
\hline & Ambient & $31.45 \pm 3.53$ & $54.81 \pm 4.99$ & $18.23 \pm 3.41$ & $824.05 \pm 81.76$ & \\
\hline \multirow[t]{2}{*}{ Autumn } & Elevated & $31.91 \pm 4.68$ & $42.71 \pm 8.91$ & $6.1 \pm 2.71$ & $490.52 \pm 171.64$ & 46,5 \\
\hline & Ambient & $28.74 \pm 4.22$ & $48.3 \pm 9.18$ & $8.33 \pm 2.63$ & $498.51 \pm 89.44$ & \\
\hline \multirow[t]{2}{*}{ Winter } & Elevated & $31.58 \pm 3.26$ & $35.45 \pm 8.63$ & $3.49 \pm 1.45$ & $1120.73 \pm 296.73$ & 13,5 \\
\hline & Ambient & $28.83 \pm 2.88$ & $39.08 \pm 9.64$ & $3.81 \pm 0.84$ & $1223.98 \pm 158.10$ & \\
\hline
\end{tabular}

OTC, open-top chamber.

Temperature, relative humidity, soil moisture content and light intensity values represent mean \pm SD. For air temperature, relative humidity, soil moisture content: $n=275$ for spring; $n=125$ for summer and autumn; $n=175$ winter. For light intensity: $n=125$ for spring, autumn and winter; $n=75$ for summer. Except for autumn light intensity, $p<0.05$ when values were compared between temperature treatments (Wilcoxon signed-rank test). 
graminoids and all life forms combined was significantly higher in OTC plots $(p<0.05$; Figure 4$)$. In terms of annual data there was also a trend for shrub productivity to be higher in OTCs, whilst forb productivity was slightly higher in control plots.

When seasonal AGP was compared between OTC and control plots, there were also no significant differences $(p>$ $0.05)$, except in autumn and spring, when graminoid productivity was higher $(p<0.05)$ in OTCs (Figure 5). Shrub productivity in summer was significantly $(p<0.05)$ higher in OTC plots. Additionally, combined productivity was significantly $(p<0.05)$ higher in OTCs in summer and autumn. Combined productivity was significantly positively correlated $(r=0.794-0.956 ; p<0.05)$ with graminoid productivity in all seasons and forb productivity in winter



FIGURE 4: Annual above-ground biomass production (g) for individual and all life forms combined. Values represent mean $\pm \operatorname{SD}(n=20)$. Values labelled with different letters are significantly different $(p<0.05$, Wilcoxon signed-rank test) when compared within life forms between temperature treatments. $(r=0.830, p<0.05)$. In summer, there was a strong negative correlation between graminoid and forb productivity $(r=-0.706, p<0.05)$. There were no significant differences $(p>0.05)$ in below-ground biomass production between OTC and control plots in individual and combined seasonal scenarios (data not shown).

Maximum temperature was significantly positively correlated with combined AGP (data for all life forms combined) in summer and autumn $(r=0.818$ and $r=0.661$, respectively; $p<0.05)$. Maximum temperature was also significantly positively correlated with graminoid AGP in summer and autumn ( $r=0.903$ and $r=0.661$, respectively; $p<0.05)$. Maximum temperature was also significantly positively correlated with shrub AGP in summer $(r=0.673$; $p<0.05)$. Minimum temperature was only significantly positively correlated with combined $(r=0.840 ; p<0.05)$ and graminoid $(r=0.850 ; p<0.05)$ AGP in autumn.

During autumn, there was a significant negative correlation between combined AGP and both RH $(r=-0.650 ; p<0.05)$ and soil moisture content $(r=-0.840 ; p<0.05)$, as well as between soil moisture content and graminoid AGP $(r=-0.765 ; p<0.05)$. Similarly, in spring there was a strong negative correlation between graminoid AGP and both RH $(r=-0.655 ; p<0.05)$ and soil moisture content $(r=-0.714$; $p<0.05)$.

Summer and annual biomass allocation to forbs was significantly $(p<0.05)$ lower in OTC plots (Figure 6). Additionally, biomass allocation to shrubs was significantly $(p<0.05)$ higher in the OTC plots in winter. Excluding summer, there were significant negative correlations between above-ground biomass allocation to graminoids and forbs $(r=-0.908$ to $-0.995, p<0.05)$. During summer there was a significant negative correlation $(r=-0.671$, $p<0.05$ ) between above-ground biomass allocation to graminoids and shrubs.

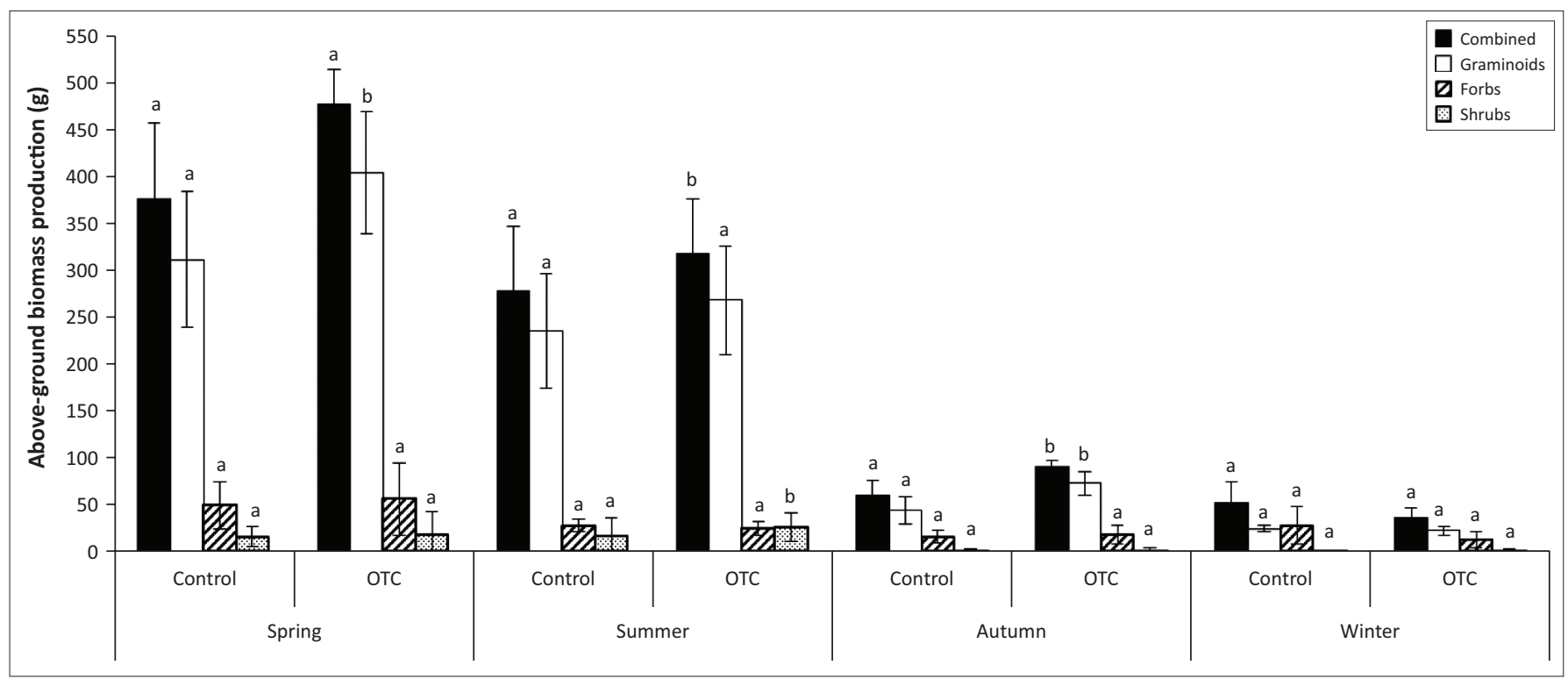

FIGURE 5: Above-ground biomass production ( $\mathrm{g}$ ) for individual and combined life forms in OTC and control plots. Values represent mean \pm SD ( $n=5$ for individual seasons) Values labelled with different letters are significantly different $(p<0.05$, Wilcoxon signed-rank test) when compared within life forms between temperature treatments. 


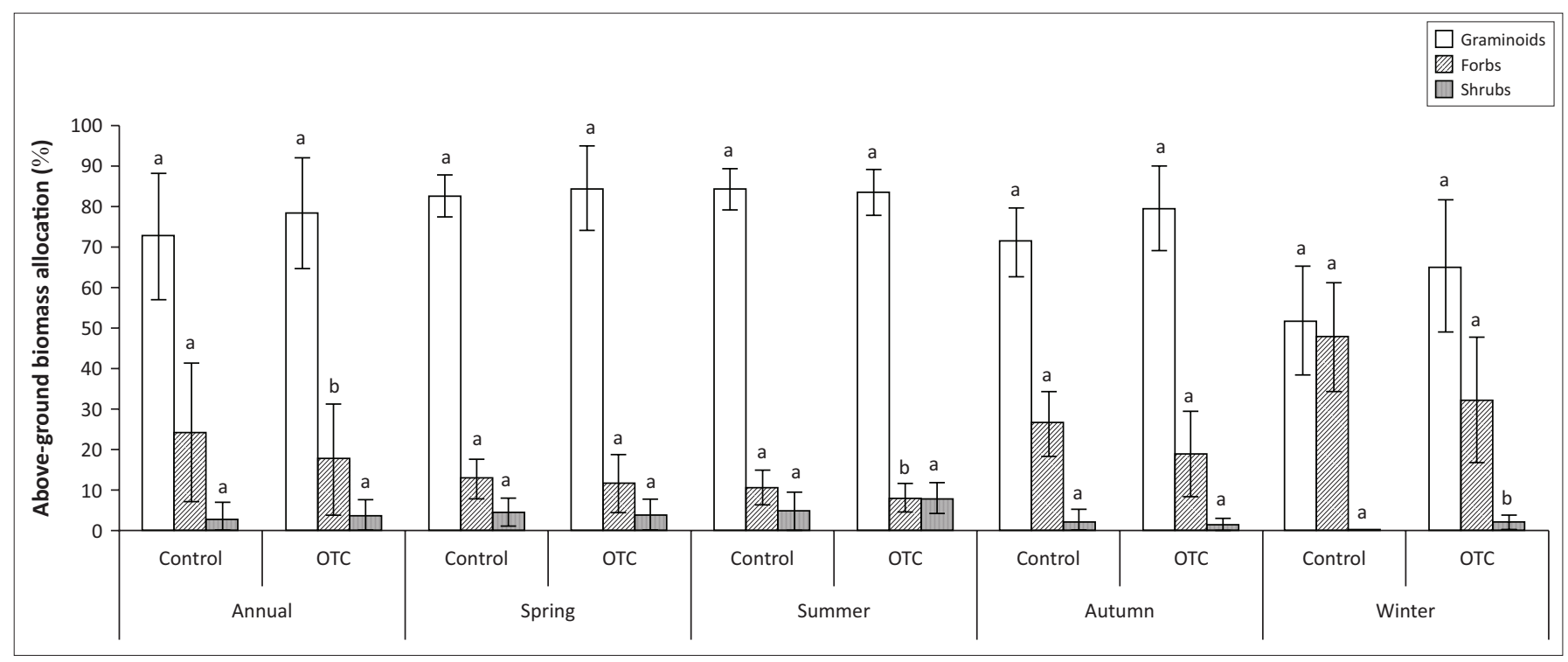

FIGURE 6: Above-ground biomass allocation (\%) for individual life forms in OTC and control plots for each season and for all seasons combined (annual). Values represent mean \pm SD ( $n=5$ for individual seasons and $n=20$ for all seasons combined) and when labelled with different letters are significantly different ( $p<0.05$, Wilcoxon signedrank test) when compared within season and life form categories, between temperature treatments.

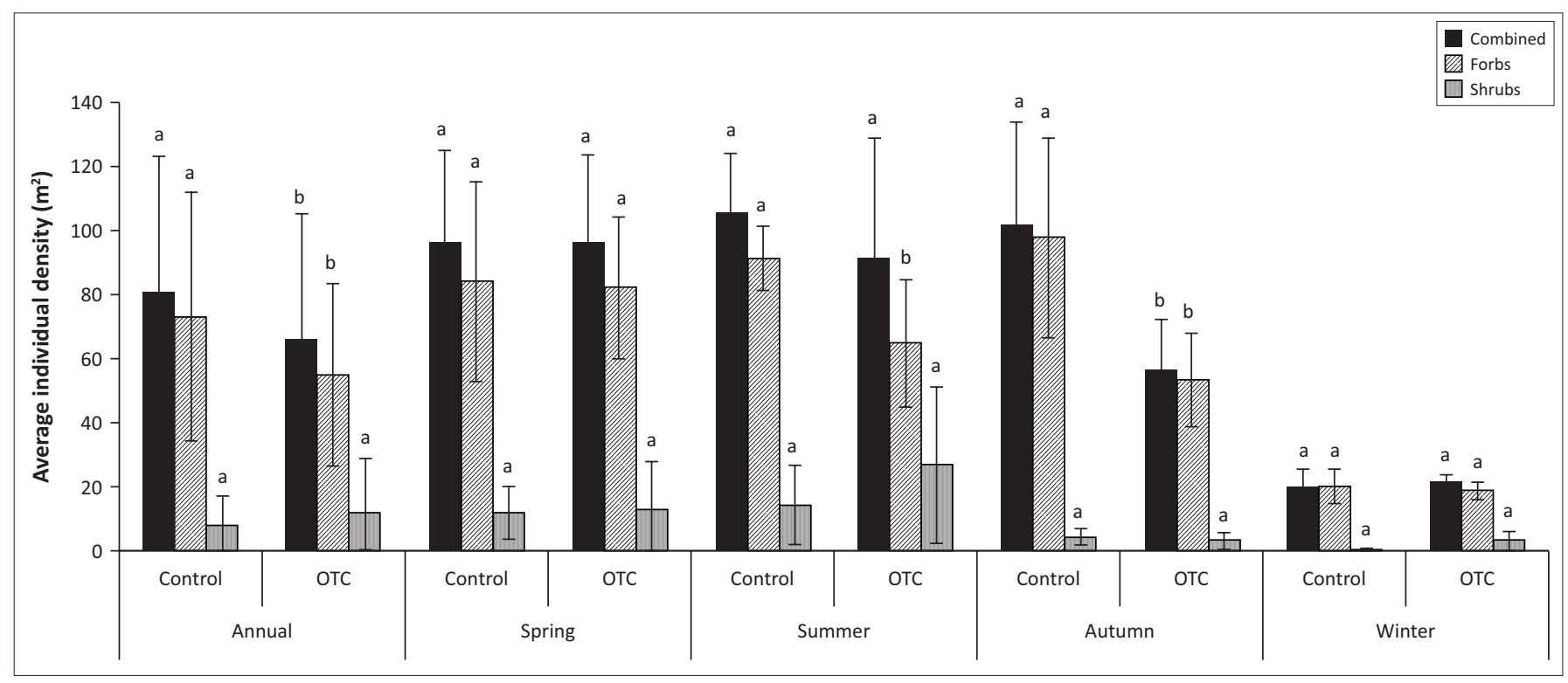

FIGURE 7: Plant density for forbs and shrubs for each season and for all seasons combined (annual). Values represent mean \pm SD $(n=20$ for combined and $n=5$ for individual seasons). Values labelled with different letters are significantly different ( $p<0.05$, Wilcoxon signed-rank test) when compared within season and life form categories, between temperature treatments.

The clonal propagation strategy adopted by many of the graminoid species sampled prevented the quantification of the graminoid density, thus density was calculated for forbs and shrubs only (Figure 7). Annual and autumn combined density was significantly lower $(p<0.05)$ in OTC plots. Annual, autumn and summer forb densities were also significantly $(p<0.05)$ lower in OTC plots, but shrubs were unaffected (Figure 7). Additionally, during autumn forb density was negatively correlated with maximum $(r=-0.669$; $p<0.05)$ and minimum $(r=-0.674 ; p<0.05)$ temperatures. In summer, there was also a significant negative correlation between maximum temperature and forb density $(r=-0.661$; $p<0.05)$. Additionally, there was a significant positive correlation between forb density and RH in autumn $(r=0.643$; $p<0.05)$. All other correlations between life forms and abiotic parameters were not significant $(p>0.05)$.

\section{Discussion}

This study assessed the utility of OTCs in simulating elevated temperatures in a subtropical grassland, and the subsequent vegetation responses to these temperatures in terms of productivity and community structure.

\section{Chamber design and effects on abiotic parameters}

The OTCs used in this study are classified as passive systems, as they primarily rely on solar energy being trapped inside the chamber, allowing no direct controlled manipulation of temperature (Marion et al. 1997). Studies on elevating temperatures with passive OTCs include many different variations on their design, which in many cases aim to reduce 
unwanted chamber effects that do not correspond to past or predicted environmental changes associated with global warming (Aronson \& McNulty 2009). The effectiveness of OTCs is based on their ability to simulate realistic elevated temperatures, i.e. temperatures that are in line within predictions for the near future. There are other methods that can be employed to elevate temperatures in plant/ecological studies (e.g. infrared heaters [Dukes et al. 2005; Sherry et al. 2008; Wan et al. 2005], in-line heaters when combined with blowers [Norby et al. 1997] and thermal inertia (water filled pipes) [Flanagan et al. 2013; Godfree et al. 2011]). However, these can be costly and cumbersome when installed in situ.

The OTC design used in this study, adapted from Molau and Mølgaard (1996), increased air and soil temperatures significantly relative to the control plots, irrespective of the time of day or season (Figure 2). More specifically, mean day temperature increased by $\pm 2.1^{\circ} \mathrm{C}$ for air and $\pm 0.3^{\circ} \mathrm{C}$ for soil, and night temperature by $\pm 0.8^{\circ} \mathrm{C}$ for air and $\pm 0.8^{\circ} \mathrm{C}$ for soil in KZNSS vegetation (when annual data were considered; Figure 3 ). The degree of air temperature increase relative to the control plots ranged from $1.6^{\circ} \mathrm{C}$ to $2.4^{\circ} \mathrm{C}$ during the day and $0.0{ }^{\circ} \mathrm{C}$ to $0.6{ }^{\circ} \mathrm{C}$ during night across the four seasons (Figure 3a). Midday temperatures measured using a precision thermistor (Kestrel 4500 Pocket Weather Tracker) (Table 2) support these findings. Further analysis of the temperature data revealed that the OTCs increased absolute maximum air and soil temperatures (Table 1). For air, this increase ranged between $4.4{ }^{\circ} \mathrm{C}$ and $5.7^{\circ} \mathrm{C}$ for absolute maximum and between $0.3{ }^{\circ} \mathrm{C}$ and $2.0{ }^{\circ} \mathrm{C}$ for absolute minimum. Godfree et al. (2011) experienced similar increases in maximum air temperature in their $70 \mathrm{~cm}$ high hexagonal chambers, with a $\pm 4.1{ }^{\circ} \mathrm{C}$ increase in spring-summer, and $\pm 5.6{ }^{\circ} \mathrm{C}$ in summer. Given that temperatures in southern Africa are likely to increase by $3{ }^{\circ} \mathrm{C}$ to $4^{\circ} \mathrm{C}$ within the century (studies cited in IPCC 2007), these data suggest that the OTC design used in this study can simulate realistic and consistent increases in temperature when installed in subtropical grasslands. Additionally, average, maximum and minimum day and night soil temperatures were significantly $(p<0.05)$ higher in OTCs in all seasons; the absolute maximum was increased by $0.9^{\circ} \mathrm{C}-1.8^{\circ} \mathrm{C}$ whilst the absolute minimum was increased by $0.3{ }^{\circ} \mathrm{C}-0.8{ }^{\circ} \mathrm{C}$ (Table 1). Rustad et al. (2001) conducted a meta-analysis on 32 various experimental projects and found that an increase in soil temperature between $0.3{ }^{\circ} \mathrm{C}$ and $6.0{ }^{\circ} \mathrm{C}$ significantly increased aboveground biomass production and soil respiration. A study in Canada revealed that OTCs with an opening of $1.0 \mathrm{~m}$ can increase mean daily soil temperatures (at $3.0 \mathrm{~cm}$ below ground level) by $0.58^{\circ} \mathrm{C}$ (Marion et al. 1997).

Marion et al. (1997) noted that the internal air and soil temperatures of OTCs are directly influenced by the ratio of the external chamber surface to the internal volume, together with the ratio of the size of the opening at the top of the chamber to the height of the chamber. A smaller internal volume and top opening of a chamber will result in increased temperatures. Additionally, Godfree et al. (2011) examined the increase in temperatures induced by OTCs with a height of $50 \mathrm{~cm}$ and $70 \mathrm{~cm}$ in a temperate grassland. When compared with the control plot, the $50 \mathrm{~cm}$ and $70 \mathrm{~cm}$ high OTCs had a mean day temperature increase of $1.2{ }^{\circ} \mathrm{C}$ and $3.2^{\circ} \mathrm{C}$, respectively, with a $0.3^{\circ} \mathrm{C}$ increase in night temperature. The chamber height used in the present study was $50 \mathrm{~cm}$ but the increases in day and night temperatures observed here were both higher than that quoted for $50 \mathrm{~cm}$ high OTCs by Godfree et al. (2011). So, whilst the chamber design used in the present study may have yielded a realistic increase in temperature for the study site selected, a larger internal volume, larger top opening and lower chamber height may have to be employed when these OTCs are installed in subtropical grasslands characterised by relatively lower present-day mean daily temperatures.

Open-top chambers are prone to numerous 'chamber effects', which include, but are not limited to, a reduction in $\mathrm{RH}$, light intensity (Flanagan et al. 2013; Godfree et al. 2011) and soil moisture content (Aronson \& McNulty 2009). Similar decreases in $\mathrm{RH}$, soil moisture content and light intensity were observed within OTCs in this study, in all seasons. There was also a strong negative correlation between $\mathrm{RH}$ and diurnal temperature in all seasons, and a positive correlation between soil moisture content and RH in the warmer seasons (i.e. spring and summer). Flanagan et al. (2013) report that in OTCs a reduction in soil moisture content may be a result of an increased vapour pressure deficit (VPD) triggered by the elevated temperatures and decreased RH. Furthermore, Rustad et al. (2001) and Wan et al. (2002) have shown that with warming there is generally always a reduction in the soil moisture content. Whilst the interaction amongst temperature, $\mathrm{RH}$ and soil moisture within OTCs are difficult to disentangle, the results obtained here and elsewhere (Aronson \& McNulty 2009; Flanagan et al. 2013; Flanagan \& Johnson 2005; Godfree et al. 2011) suggest that OTCs offer the opportunity to investigate the combined effects of elevated temperatures and reduced soil moisture content in grasslands - both of which have been predicted for subtropical grasslands (IPCC 2007). The decline in light intensity in the OTCs was marginal $\left(70.59-110.39 \mu \mathrm{mol} \mathrm{m}^{-2} \mathrm{~s}^{-1}\right)$, given that maximum light intensities measured ranged from 900 to $1200 \mu \mathrm{mol} \mathrm{m} \mathrm{m}^{-2}$. Reference to the literature suggests that a significant decline in light intensity can reduce graminoid productivity in grassland vegetation (Olff 1992). In the present study, graminoid productivity increased within the OTCs, implying that the reduction in light intensity within the chambers was not significant enough to override the effects of temperature.

The modifications to the ITEX design made here (e.g. increased chamber size and improved support frame) were to allow the chambers to withstand the heavy summer rains, unpredictable hail storms and strong wind gusts associated with the study area. Even with these modifications, each chamber could be manufactured for less than $\$ 70$, making them a very affordable experimental tool for studies focused on grassland responses to climate change. 


\section{Plant productivity and community structure}

Studies have shown that increased temperature can influence floristics and community structure in temperate grasslands (Saleska et al. 2002; Shaver et al. 2000). Elevated temperatures can alter recruitment patterns, influencing community composition and species richness, both of which have a bearing on ecosystem health (De Boeck et al. 2007; Laurance et al. 2011). Studies in temperate systems have also shown that elevated temperatures can alter productivity in grasslands, which has implications for ecosystem functioning (Dukes et al. 2005).

According to Wan et al. (2005), elevated temperatures could have both a positive and a negative effect on the carbon sequestration in grasslands, depending on the season, as well as an indirect effect by extending the growing season and altering soil nitrogen mineralisation and availability. This may explain reports of mixed responses of carbon sequestration to elevated temperatures in grasslands (Jones \& Donnelly 2004).

In the present study, elevated temperatures increased annual graminoid AGP by $\pm 19.9 \%$ and decreased forb AGP by $\pm 9.0 \%$ (Figure 4 ). In terms of annual combined AGP, levels in OTC plots were also $\pm 16.9 \%$ higher compared to control plots (Figure 4). Additionally, at elevated temperatures graminoid AGP was significantly higher in spring and autumn, shrub AGP was significantly higher in summer, and combined AGP was significantly higher in summer and autumn (Figure 5). These results are largely understandable as spring and summer represent the major growing seasons in subtropical grasslands. The increase in graminoid and combined AGP within OTCs in autumn (Figure 5) suggests that elevated temperatures may also increase biomass production during periods of low productivity and low rainfall. This study was conducted in a summer rainfall region in southern Africa, where precipitation can vary between 640 and $1800 \mathrm{~mm}$ (Neumann, Botha \& Scott 2014); the highest precipitation occurs in spring and summer under increased $\mathrm{RH}$ and temperature, and rainfall deficit during autumn and winter under increased evaporation (Neumann et al. 2014). The potential interactions between elevated temperatures and rainfall deserve further investigation.

Graminoid AGP was positively correlated with diurnal, maximum and minimum temperatures in autumn, and with maximum temperatures in summer when correlated. Furthermore, during summer graminoid AGP was significantly negatively correlated with forb AGP; this also was evidenced by the significant decline in biomass allocation to forbs at elevated temperatures (for annual and summer, Figure 6). This suggests that in KZNSS, elevated temperatures in promoting graminoid productivity may compromise forb AGP. Interestingly, shrub AGP was significantly enhanced at elevated temperatures in summer (Figure 5). Del-Val and Crawley (2005) observed a reduction in forb and shrub AGP with increased grass biomass. Those authors also showed monocotyledonous species to be stronger competitors within grasslands than forbs or shrubs, and that removal of grasses led to a dramatic increase in forb and shrub AGP. They suggested that competition for light could be the main driver in these competitive interactions. Carlsen, Menke and Pavlik (2000) also suggest that grasses, in forming dense swards, could possibly cause a reduction in the quality and quantity of light reaching forb species below. However, these studies did not manipulate temperature, and at the time of this study there were no recently published data on in situ responses of subtropical grassland species to elevated temperature. Nevertheless, Morgan et al. (2011) showed that $C_{4}$ grass responded positively to elevated temperatures in terms of AGP; however, small population sizes and yearly variation reduced detectable effects on forbs. This may have also contributed to the lack of significant differences observed in the present study.

Typically, $\mathrm{C}_{4}$ grasses dominate tropical and subtropical grasslands (Still et al. 2003). These $C_{4}$ species have higher thermal thresholds than $C_{3}$ species such as forbs, largely as a consequence of differences in the enzyme they employ for carbon fixation (De Boeck et al. 2007; Hatfield \& Prueger 2015; Wan et al. 2002). The ability of graminoids (mainly $\mathrm{C}_{4}$ species) to enhance their productivity at elevated temperatures is well documented (Horton \& Murchie 2000; Sage 2000), whereas at these temperatures, forbs (mainly $\mathrm{C}_{3}$ species) could be reaching their thermal maximum temperatures, triggering a reduction in their photosynthetic efficiency and hence, productivity (De Boeck et al. 2007; Hatfield \& Prueger 2015; Wan et al. 2002). Whilst graminoid AGP was enhanced at elevated temperatures in the present study (as described above), forb AGP was not correlated with temperature, $\mathrm{RH}$ or soil moisture content. On the other hand, graminoid AGP was negatively correlated within both $\mathrm{RH}$ and soil moisture content in spring, the season of maximum growth. This implies that the increase in grass productivity at elevated temperatures in KZNSS may have led to a decrease in soil water availability. This is worrying because forbs and shrubs have an inferior water-use-efficiency to graminoids (Sherry et al. 2008; Wan et al. 2005).

It is also worth noting that winter biomass allocation percentages in control plots were more comparable between forbs and graminoids than in OTC plots (Figure 6). This difference appears to be the result of a decrease $(18.2 \%$ relative to control) in forb AGP in the OTC plots in winter and suggests that elevated temperature effects may manifest during times of minimal growth within KZNSS as well. This suggestion is reinforced by the fact that forb density within the OTCs was lower than the control plots for autumn, summer and annual data (Figure 7). Additionally, there was also a strong negative correlation between forb density and both maximum and minimum temperatures in autumn and between forb density and maximum temperature in summer. Alward et al. (1999), in examining 23 years of correlation data between temperature (minimum, maximum and average), AGP and abundance, showed that native and exotic forbs in cold temperate grasslands exhibited increased net primary productivity (NPP) and density at elevated temperatures. 
However, they stated that this result may be a consequence of the decreased annual NPP of a dominant $\mathrm{C}_{4}$ grass, resulting in increased space, nutrients and water availability, rather than the effects of elevated temperatures. It should be noted that although graminoid densities were not recorded in the present study, they displayed $90 \%-100 \%$ coverage in most control and OTC plots. Carlsen et al. (2000) showed that high density grasslands provided a poor habitat for native forbs. Furthermore, Sternberg et al. (1999) predicted that an increase in graminoid productivity will result in decreased availability of gaps for forb recruitment or growth, and consequently a reduction in the forb species richness and density. This is very concerning because many of the forb and shrub species endemic to KZNSS are taxa of conservation concern (Mucina \& Rutherford 2006).

\section{Concluding remarks and recommendations}

The effects of climate change are becoming increasingly evident and the need to predict ecosystem responses to increased temperatures, in particular, is of paramount importance. This is particularly true for grasslands, which are threatened worldwide. The present study has shown that the effects of elevated temperatures on subtropical grasslands can be successfully investigated in situ using OTCs. The elevated temperatures simulated by these OTCs appear to be in line with predictions for the next century and accompanying 'chamber effects', such as decreased soil moisture content, may allow for the simultaneous investigation of different climate change scenarios.

The results suggest that the responses of KZNSS vegetation to elevated temperatures will vary across life forms, with $\mathrm{C}_{4}$ graminoids appearing to benefit in terms of AGP. There were also signs that this enhanced graminoid productivity at elevated temperatures may lead to the displacement of $\mathrm{C}_{3}$ forbs, possibly as a result of competition. Shrubs, on the other hand, appear to be unaffected (both directly and indirectly) by elevated temperatures. The effects of elevated temperatures on KZNSS are likely to manifest during periods of maximum and minimum growth. This has implications for KZNSS conservation planning efforts.

We, therefore, recommend the use of OTCs in future investigations of the effects of elevated temperatures on subtropical grasslands. Apart from productivity, such studies should investigate how elevated temperatures are likely to influence species composition and abundance, which will yield more informed recommendations for the conservation of threatened grassland types like KZNSS.

\section{Acknowledgements}

This research was supported by eThekwini Municipality through the Durban Research Action Partnership: KwaZuluNatal Sandstone Sourveld Research Programme. Numerous field assistants are thanked for their assistance. The Walker family of Tanglewood Nature Reserve are thanked for permission to use the reserve and supporting this study. S.R. thanks UKZN for research support. This research was funded by the NRF Thuthuka programme (grant number 84449).

\section{Competing interests}

The authors declare that they have no financial or personal relationship(s) that may have inappropriately influenced them in writing this article.

\section{Authors' contributions}

R.D.B. carried out the field work, processed and analysed the data and wrote the manuscript. The study was supervised by S.N., S.R. and N.W.P., who also made contributions to the manuscript.

\section{References}

Ahuja, I., de Vos, R.C., Bones, A.M. \& Hall, R.D., 2010, 'Plant molecular stress responses face climate change', Trends in Plant Science 15(12), 664-674. http://dx.doi. org/10.1016/j.tplants.2010.08.002

Alward, R.D., Detling, J.K. \& Milchunas, D.G., 1999, 'Grassland vegetation changes and nocturnal global warming', Science 283(5399), 229-231. http://dx.doi. org/10.1126/science.283.5399.229

Aronson, E.L. \& McNulty, S.G., 2009, 'Appropriate experimental ecosystem warming methods by ecosystem, objective, and practicality', Agricultural and Forest Meteorology 149, 1791-1799. http://dx.doi.org/10.1016/j.agrformet.2009. Meteor
06.007

Beerling, D.J., Osborne, C.P. \& Chaloner, W.G., 2001, 'Evolution of leaf-form in land plants linked to atmospheric CO decline in the Late Palaeozoic era', Nature 410 352-354. http://dx.doi.org/10.1038/35066546

Boval, M. \& Dixon, R.M., 2012, 'The importance of grasslands for animal production and other functions: a review on management and methodological progress in the tropics', Animal 6(5), 748-762. http://dx.doi.org/10.1017/S175173111 2000304

Carlsen, T.M., Menke, J.W. \& Pavlik, B.M., 2000, 'Reducing competitive suppression of a rare annual forb by restoring native California perennial grasslands', Restoration Ecology 8(1), 18-29. http://dx.doi.org/10.1046/j.1526-100x.2000.80004.x

De Boeck, H.J., Lemmens, C.M.H.M., Gielen, B., Bossuyt, H., Malchair, S., Carnol, M., et al., 2007, 'Combined effects of climate warming and plant diversity loss on above-and below-ground grassland productivity', Environmental and Experimental Botany 60(1), 95-104. http://dx.doi.org/10.1016/j.envexpbot.2006.07.001

Del-Val, E.K. \& Crawley, M.J., 2005, 'What limits herb biomass in grasslands: competition or herbivory?', Oecologia 142(2), 202-211. http://dx.doi.org/10. 1007/s00442-004-1719-8

Dhillon, R.S. \& von Wuehlisch, G., 2013, 'Mitigation of global warming through renewable biomass', Biomass and Bioenergy 48, 75-89. http://dx.doi. org/10.1016/j.biombioe.2012.11.005

Dukes, J.S., Chiariello, N.R., Cleland, E.E., Moore, L.A., Shaw, M.R., Thayer, S., et al., 2005, 'Responses of grassland production to single and multiple global environmental changes', PLoS Biology 3(10), e319. http://dx.doi.org/10.1371/ journal.pbio.0030319

Egoh, B.N., Reyers, B., Rouget, M. \& Richardson, D.M., 2011, 'Identifying priority areas for ecosystem service management in South African grasslands', Journal of Environmental Management 92(6), 1642-1650. http://dx.doi.org/10.1016/j. jenvman.2011.01.019

Farooq, M., Flower, K.C., Jabran, K., Wahid, A. \& Siddique, K.H., 2011, 'Crop yield and weed management in rainfed conservation agriculture', Soil and Tillage Research 117, 172-183. http://dx.doi.org/10.1016/j.still.2011.10.001

Flanagan, L.B. \& Johnson, B.G., 2005, 'Interacting effects of temperature, soil moisture and plant biomass production on ecosystem respiration in a northern temperate grassland', Agricultural and Forest Meteorology 130(3-4), 237-253. http://dx.doi. org/10.1016/j.agrformet.2005.04.002

Flanagan, L.B., Sharp, E.J. \& Letts, M.G., 2013, 'Response of plant biomass and soil respiration to experimental warming and precipitation manipulation in a Northern Great Plains grassland', Agricultural and Forest Meteorology 173, 40-52. http:// dx.doi.org/10.1016/j.agrformet.2013.01.002

Girardin, C.A.J., Malhi, Y., Aragao, L.E.O.C., Mamani, M., Huaraca Huasco, W., Durand, L., et al., 2010, 'Net primary productivity allocation and cycling of carbon along a tropical forest elevational transect in the Peruvian Andes', Global Change Biology 16(12), 3176-3192. http://dx.doi.org/10.1111/j.1365-2486.2010.02235.x

Godfree, R., Robertson, B., Bolger, T., Carnegie, M. \& Young, A., 2011, 'An improved hexagon open-top chamber system for stable diurnal and nocturnal warming and atmospheric carbon dioxide enrichment', Global Change Biology 17(1), 439-451. $\mathrm{http}: / / \mathrm{dx}$.doi.org/10.1111/j.1365-2486.2010.02276.x 
Gowik, U. \& Westhoff, P., 2011, 'The path from C to C photosynthesis', Plant Physiology 155(1), 56-63. http://dx.doi.org/10.1104/pp.110.165308

Guoju, X., Weixiang, L., Qiang, X., Zhaojun, S. \& Jing, W., 2005, 'Effects of temperature increase and elevated CO 2 concentration, with supplemental irrigation, on the yield of rain-fed spring wheat in a semiarid region of China', Agricultural Water Management 74(3), 243-255. http://dx.doi.org/10.1016/j.agwat.2004.11.006

Hatfield, J.L. \& Prueger, J.H., 2015, 'Temperature extremes: effect on plant growth and development', Weather and Climate Extremes 10, 4-10. http://dx.doi. org/10.1016/j.wace.2015.08.001

Horton, P. \& Murchie, E.H., 2000, 'C 4 photosynthesis in rice: some lessons from studies of ' $C_{3}$ photosynthesis in field-grown rice', Studies in Plant Science 7, 127-144. http://dx.doi.org/10.1016/S0928-3420(00)80011-7

Intergovernmental Panel Climate Change (IPCC), 2007, 'Climate change 2007: impacts, adaptation and vulnerability: contribution of working group II to the fourth assessment report of the intergovernmental panel on climate change', Cambridge University Press, Cambridge, UK.

Jewitt, D., 2011, Conservation targets and status for vegetation types in KZN, Ezemvelo KwaZulu-Natal Wildlife, Biodiversity Conservation Planning Division, Pietermaritzburg, South Africa.

Jones, M.B. \& Donnelly, A., 2004, 'Carbon sequestration in temperate grassland ecosystems and the influence of management, climate and elevated $\mathrm{CO}_{2}^{\prime}, \mathrm{New}$ Phytologist164(3),423-439.http://dx.doi.org/10.1111/j.1469-8137.2004.01201.x

Lattanzi, F.A., 2010, 'C3/C4 grasslands and climate change', Grassland Science in Europe 15, 3-13.

Laurance, W.F., Useche, D.C., Shoo, L.P., Herzog, S.K., Kessler, M., Escobar, F., et al. 2011, 'Global warming, elevational ranges and the vulnerability of tropical biota', Biological Conservation 144(1), 548-557. http://dx.doi.org/10.1016/j. biocon.2010.10.010

Long, S.P., 1999, 'Environmental responses', in R.F. Sage \& R.K. Monson (eds.), The biology of $C_{4}$ photosynthesis, pp. 215-249, Academic Press, San Diego, CA.

Long, S.P. \& Hutchin, P.R., 1991, 'Primary production in grasslands and coniferous forests with climate change: an overview', Ecological Applications 1(2), 139-156. $\mathrm{http}: / / \mathrm{dx}$.doi.org/10.2307/1941807

Luo, W., Jiang, Y., Lü, X., Wang, X., Li, M.H., Bai, E., et al., 2013, 'Patterns of plant biomass allocation in temperate grasslands across a $2500-\mathrm{km}$ transect in northern China', PLoS One 8(8), e71749. http://dx.doi.org/10.1371/journal.pone.0071749

Marion, G.M. Henry, G.H.R., Freckman, D.W. Johnstone, J., Jones, G., Jones, M.H et al., 1997, 'Open-top designs for manipulating field temperature in high-latitude
ecosystems', Global Change Biology 3(S1), 20-32. http://dx.doi.org/10.1111/j. ecosystems', Global Chang

Molau, U. \& Mølgaard, P., 1996, International tundra experiment (ITEX) manual, Danish Polar Center, Copenhagen, Denmark.

Morgan, J.A., LeCain, D.R., Pendall, E., Blumenthal, D.M., Kimball, B.A., Carrillo, Y., et al., 2011, ' $C_{4}$ grasses prosper as carbon dioxide eliminates desiccation in warmed semi-arid grassland', Nature 476, 202-205. http://dx.doi.org/10.1038/ nature10274

Mucina, L. \& Rutherford, M.C., 2006, The vegetation of South Africa, Lesotho and Swaziland, Strelitzia 19, South African National Biodiversity Institute, Pretoria.

Neumann, F.H., Botha, G.A. \& Scott, L., 2014, '18,000 years of grassland evolution in the summer rainfall region of South Africa: evidence from Mahwaqa Mountain KwaZulu-Natal', Vegetation History and Archaeobotany 23(6), 665-681. http:// dx.doi.org/10.1007/s00334-014-0445-3

Norby, R., Edwards, N., Riggs, J., Abner, C., Wullschleger, S. \& Gunderson, C., 1997 'Temperature-controlled open-top chambers for global change research', Global Change Biology 3(3), 259-267. http://dx.doi.org/10.1046/j.1365-2486.1997. 00072.x

Ojima, D.S., Parton, W.J., Schimel, D.S., Scurlock, J.M. \& Kittel, T.G., 1993, 'Modeling the effects of climatic and $\mathrm{CO}_{2}$ changes on grassland storage of soil C', Water, Air, and Soil Pollution 70, 643-657. http://dx.doi.org/10.1007/BF01105027

Olff, H., 1992, 'Effects of light and nutrient availability on dry matter and $\mathrm{N}$ allocation in six successional grassland species', Oecologia 89(3), 412-421. http://dx.doi. org/10.1007/BF00317420

Parr, C.L., Lehmann, C.E., Bond, W.J., Hoffmann, W.A. \& Andersen, A.N., 2014, 'Tropical grassy biomes: misunderstood, neglected, and under threat', Trends in Ecology \& Evolution 29(4), 205-213. http://dx.doi.org/10.1016/j.tree.2014.02.004

Perez, T.M., Stroud, J.T. \& Feeley, K.J., 2016, 'Thermal trouble in the tropics', Science 351(6280), 1392-1393. http://dx.doi.org/10.1126/science.aaf3343

Potter, C., Klooster, S. \& Genovese, V., 2012, 'Net primary production of terrestrial ecosystems from 2000 to 2009', Climatic Change 115(2), 365-378. http://dx.doi. org/10.1007/s10584-012-0460-2
Reyers, B., Nel, J., Egoh, B., Jonas, Z. \& Rouget, M., 2005, 'National Grasslands Biodiversity Programme: Grassland Biodiversity Profile and Spatial Biodiversity Priority Assessment', Report for the South African National Biodiversity Institute's Priority Assessment', Report for the South African National Biodiversity Institute's
National Grasslands Biodiversity Programme, CSIR report number: ENV-S-C 2005102, CSIR, Stellenbosch.

Rustad, L.E.J.L., Campbell, J., Marion, G., Norby, R., Mitchell, M., Hartley, A., et al., 2001, 'A meta-analysis of the response of soil respiration, net nitrogen mineralization, and aboveground plant growth to experimental ecosystem warming', Oecologia 126(4), 543-562. http://dx.doi.org/10.1007/s004420000544

Sage, R.F., 2000, ' $C_{3}$ versus $C_{4}$ photosynthesis in rice: ecophysiological perspectives', Studies in Plant Science 7, 13-35. http://dx.doi.org/10.1016/S0928-3420(00) 80004-X

Sala, O.E., Chapin, F.S., Armesto, J.J., Berlow, E., Bloomfield, J., Dirzo, R., et al., 'Globa biodiversity scenarios for the year 2100', Science 287(5459), 1770-1774. http:// dx.doi.org/10.1126/science.287.5459.1770

Saleska, S.R., Shaw, M.R., Fischer, M.L., Dunne, J.A., Still, C.J., Holman, M.L. et al., 2002, 'Plant community composition mediates both large transient decline and predicted long-term recovery of soil carbon under climate warming', Global Biogeochemical Cycles 16(4), 1055. http://dx.doi.org/10.1029/2001GB001573

Saxe, H., Cannell, M.G., Johnsen, $\varnothing$., Ryan, M.G. \& Vourlitis, G., 2001, 'Tree and forest functioning in response to global warming', New Phytologist 149(3), 369-399. http://dx.doi.org/10.1046/j.1469-8137.2001.00057.x

Scheiter, S. \& Higgins, S.I., 2009, 'Impacts of climate change on the vegetation of Africa: an adaptive dynamic vegetation modelling approach', Global Change Biology 15(9), 2224-2246. http://dx.doi.org/10.1111/j.1365-2486.2008.01838.x

Schindlbacher, A., Zechmeister-Boltenstern, S. \& Jandl, R., 2009, 'Carbon losses due to soil warming: do autotrophic and heterotrophic soil respiration respond equally?', Global Change Biology 15(4), 901-913. http://dx.doi.org/10.1111/j.1365-2486. Global Chang
2008.01757.x

Shaver, G.R., Canadell, J., Chapin, F.S., Gurevitch, J., Harte, J., Henry, G., et al., 2000 'Global warming and terrestrial ecosystems: a conceptual framework for analysis', BioScience 50(10), 871-882. http://dx.doi.org/10.1641/0006-3568(2000)050 BioScience 50(10), $871-8$
[0871:GWATEA]2.0.CO;2

Sherry, R.A., Weng, E., Arnone III, J.A., Johnson, D.W., Schimel, D.S., Verburg, P.S., et al., 2008, 'Lagged effects of experimental warming and doubled precipitation on annual and seasonal aboveground biomass production in a tallgrass prairie', GlobalChange Biology14(12), 2923-2936. http://dx.doi.org/10.1111/j.1365-2486. 2008.01703.x

Sternberg, M., Brown, V.K., Masters, G.J. \& Clarke, I.P., 1999, 'Plant community dynamics in a calcareous grassland under climate change manipulations', Plant Ecology 143(1), 29-37. http://dx.doi.org/10.1023/A:1009812024996

Still, C.J., Berry, J.A., Collatz, G.J. \& DeFries, R.S., 2003, 'Global distribution of C and C vegetation: carbon cycle implications', Global Biogeochemical Cycles 17(1), 1006. http://dx.doi.org/10.1029/2001GB001807

Thuiller, W., Albert, C., Araújo, M.B., Berry, P.M., Cabeza, M., Guisan, A., et al., 2008 'Predicting global change impacts on plant species' distributions: future challenges', Perspectives in Plant Ecology, Evolution and Systematics 9(3), 137-152. http://dx.doi.org/10.1016/j.ppees.2007.09.004

Trisurat, Y., Shrestha, R.P. \& Kjelgren, R., 2011, 'Plant species vulnerability to climate change in Peninsular Thailand', Applied Geography 31(3), 1106-1114. http://dx. doi.org/10.1016/j.apgeog.2011.02.007

Trollope, W.S.W., Trollope, L.A. \& Hartnett, D.C., 2002, 'Fire behaviour a key factor in the fire ecology of African grasslands and savannas', in D.X. Viegas (ed.), Proceedings of IV international conference on forest fire research 2002: forest fire research \& wildland fire safety, pp. 1-16, Millpress, Rotterdam.

Van Acker, R.C., Bullied, W.J. \& du Croix Sissons, M.J., 2004, 'Tillage index predicts weed seedling recruitment depth', Canadian Journal of Plant Science 84(1), 319-326. http://dx.doi.org/10.4141/P03-074

Wan, S., Hui, D., Wallace, L. \& Luo, Y., 2005, 'Direct and indirect effects of experimental warming on ecosystem carbon processes in a tallgrass prairie', Global Biogeochemical Cycles 19(2), GB2014. http://dx.doi.org/10.1029/2004GB002315

Wan, S., Luo, Y. \& Wallace, L.L., 2002, 'Changes in microclimate induced by experimental warming and clipping in tallgrass prairie', Global Change Biology 8(8), 754-768. http://dx.doi.org/10.1046/j.1365-2486.2002.00510.x

Wand, S.J., Midgley, G., Jones, M.H. \& Curtis, P.S., 1999, 'Responses of wild C4 and C3 grass (Poaceae) species to elevated atmospheric $\mathrm{CO}_{2}$ concentration: a metaanalytic test of current theories and perceptions', Global Change Biology 5(6), 723-741. http://dx.doi.org/10.1046/j.1365-2486.1999.00265.x

Williams, D. \& Scott, R.L., 2009, 'Vegetation-hydrology interactions: dynamics of riparian plant water use', in J.C. Stromberg \& B. Tellman (eds.), Ecology and conservation of the San Pedro River, pp. 37-56, University of Arizona Press, Tucson. 